\title{
Skysčio ir dujų srautų dinamikos kanaluose tyrimai tūrio, debito ir greičio matavimų tikslumui didinti
}

Antanas Pedišius,

Jurij Tonkonogij,

Nerijus Pedišius,

Gediminas Zygmantas,

Arūnas Stankevičius,

Andrius Tonkonogovas,

Agnẻ Bertašienè,

Eugenijus Maslauskas,

Paulius Vilkinis

Lietuvos energetikos institutas, Šiluminiu îrengimu tyrimo ir bandymų laboratorija, Breslaujos g. 3, LT-44403 Kaunas El.paštas Antanas.Pedisius@lei.lt
Straipsnyje pateikiama apžvalga pagrindinių mokslinių tyrimų ir eksperimentinès plètros darbų, kuriuos nuo 2006 iki 2016 m. vykdè Lietuvos energetikos instituto Šiluminių iૃrengimų tyrimo ir bandymų laboratorija. Pagrindiniai moksliniai dujų ir skysčiu dinamikos tyrimai buvo nukreipti ị dujų ir skysčiu tūrio, debito ir greičio matavimo tikslumo priklausomumą nuo srauto pulsacijų, kinematinès klampos ir tekejjimo režimo pokyčių. Nustatyti universalūs tachometrinių matuoklių dinaminių paklaidų dèsningumai, esant ịvairiems srauto trukdžiams, panaudoti srautų matavimo neapibrèžtims vertinti. Šie dessningumai taip pat panaudoti kuriant ir tobulinant pagal Lietuvos Respublikos Vyriausybès igaliojimus keturis valstybinius oro (dujų) greičio vieneto ir oro (dujų), vandens ir naftos produktų tūrio bei debito vienetų etalonus. Etalonų matavimo ir kalibravimo galimybès ivertintos remiantis tarptautine praktika, patvirtintos, visuotinai pripažintos ir paskelbtos Tarptautinio svarsčių ir matų biuro (BIPM) svetaineje. Išplètota techninè tyrimų ir bandymų bazè bei ūkio ir mokslo subjektams teikiamos paslaugos sukūrè reikiamas sąlygas matavimų infrastruktūrai Lietuvoje tinkamai funkcionuoti ir užtikrinti praktikoje naudojamų, gaminamų bei tiekiamų ị rinką dujų ir skysčių srautų matavimo priemonių atitikties reikalavimams vertinimus.

Taip pat pateikiami pradiniai perspektyvių srautų dinamikos mikrokanaluose su struktūrizuotais paviršiais tyrimų rezultatai ir taikymai naudojant dalelių sraute vizualizavimo metodą.

Raktažodžiai: debitas, tūrio ir debito matavimai, tachoetriniai matuokliai, pulsuojantis srautas, kintamoji dujų ir skysčių klampa, dinaminè paklaida, srautu etalonai

\section{IVADAS}

Per pastarąji dešimties metų veiklos laikotarpi (2006-2016 m.) instituto Šiluminių įrengimų tyrimo laboratorija vykde MTEP patvirtintos mokslo krypties „Šiluminès fizikos, dujų ir skysčių dinamikos ir metrologijos tyrimai“ darbus, sutelkdama pagrindinị dèmesị ị dujų ir skysčių dinamikos sudètingos geometrijos kanaluose tyrimus, susietus su pertekančių srautų tūrio, debito ir greičio matavimo tikslumą trikdančiais veiksniais.

Mokslinès ir praktinès žinios apie skysčiu ir dujų tekèjimo dinamiką yra labai svarbus aspektas sprendžiant esamus ir perspektyvius mokslinius bei taikomuosius uždavinius, susijusius su masès ir šilumos pernašos procesų intensyvinimu, energijos konversijos efektyvumo didinimu ir emisijų mažinimu bei energetinių išteklių apskaitos tikslumo užtikrinimu, plètojant tarptautinius prekių ir paslaugų mainus, ùkio raidą ir gamintojų konkurencingumo didinimą bei šalies rinkos apsaugą nuo netinkamų gaminių ir paslaugų. Energetinių išteklių matavimo tikslumas pastaruoju metu igavo dar daugiau svarbos dèl jų poreikio ir kainų didejjimo, reikalavimų kuo efektyviau juos panaudoti ir nuolat augančio ju vaidmens tarptautiniuose prekių mainuose. 
Todèl visos Europos šalys yra issteigusios ir plètoja nacionalinius matavimų institutus, kurie daugiausia ir padeda šalių matavimų ir atitikties vertinimo infrastruktūroms tinkamai funkcionuoti. Šie nacionaliniai subjektai yra nariai regioninès metrologinès EURAMET organizacijos, kurios paskirtis - kartu su kitomis analogiškomis regioninèmis organizacijomis (SIM (Inter-American Metrology System), AFRIMETS (Intra-Africa Metrology System), APMP (Asia Pacific Metrology Programme) ir COOMET (Euro-Asian Cooperation of NMIs)) patikimai užtikrinti šalių bendradarbiavimą matavimų siečiai ne tik Europoje, bet ir pasauliniu mastu. Tuo tikslu nacionaliniai matavimų institutai vykdo mokslinius ir eksperimentinès plètros darbus, bendradarbiauja tarpusavyje atlikdami tarptautinius matavimų palyginimus ir jungtinius projektus, kurių bendras tikslas - užtikrinti šalyse matavimų lygi, o mokslo ir ūkio subjektams - paslaugas, atitinkančias pasiektą aukščiausią techninį ir mokslinị lygị.

Lietuvos energetikos institutas, vykdydamas Lietuvos Respublikos Vyriausybès igaliojimus ir atsižvelgdamas ị bendruosius Europos Sąungos šalių ūkio ir mokslo funkcionavimo ir plètros principus, pavedè Šiluminių ịrengimų tyrimo ir bandymų laboratorijai vykdyti paskirtojo instituto funkcijas - sukurti keturis valstybinius etalonus oro (dujų) greičio, debito ir tūrio bei vandens ir naftos produktų debito ir tūrio vienetų vertèms atkurti, užtikrinti šių dydžių matavimų sietị su Europos šalių nacionalinių matavimo institutų teikiamomis pamatinemis vertemis, atstovauti Lietuvai EURAMET techniniame komitete Srautai ir periodiškai patvirtinti veiklos rezultatus EURAMET techniniame komitete Kokybe.

Kadangi srautu etalonų labai svarbią dalị sudaro aerodinaminiai ir hidrodinaminiai ịrenginiai oro bei skysčių srautams sukurti ir juos tinkamai valdyti, pastarieji iš esmès buvo konstruojami, gaminami, tiriami ir ịteisinami naudojant daugiausia vidinius instituto išteklius ir, kur tinkama, Lietuvos verslo subjektų paslaugas. Todèl daug dèmesio buvo skiriama moksliniams srautų dinamikos matuoklių kanaluose tyrimams ir inovatyvios matavimų įrangos diegimo pletrai. Ekonomiškumo požiūriu tai buvo ir išlieka efektyviausiu būdu sukurti ir tobulinti valstybinių etalonų techninę bazę bei lanksčiai derinti jos galimybes, atsižvelgus ị Lietuvos ūkio ir mokslo poreikius bei tarptautinius matavimų lygmens pokyčius. Jau iki $2006 \mathrm{~m}$. buvo sukurta ir ịteisinta etalonų techninè bazè ir jos kalibravimo bei matavimo galimybès $[1,2]$.

Toliau šiame straipsnyje apibendrinami per pastarajji dešimtmetị laboratorijos atliktų mokslinių tyrimų ir etalonų matavimo galimybių gerinimo darbų rezultatai siekiant priartinti sukurtų etaloninių i̇renginių matavimo galimybes prie pagrindinių Europos šalių nacionalinių institutų galimybių lygmens. Taip pat pateikiama trumpa informacija apie veiklos pripažinimą ir vertinimą, taikomųjų darbų ir paslaugų teikiamas apimtis, svarbą bei perspektyvas.

\section{PAGRINDINIAI SRAUTŲ DINAMIKOS MOKSLINIŲ TYRIMŲ REZULTATAI}

\section{Tyrimo objektai ir tikslai}

Svarbiausi rezultatai gauti tiriant mechaninių matuoklių su besisukančiais rotoriais (toliau - tachometriniai matuokliai) matavimo rezultatų priklausomumą nuo hidrodinaminių trukdžių, sukeliamų matuojamojo srauto pulsacijų, ir skysčių bei dujų fizikinès klampos pokyčių, kurias lemia skysčio rūšis arba dujų slègis. Nepaisant naujų tekančių skysčių ir dujų kiekio, debito ir greičio matavimo metodų tyrimų ir taikymų plètros, mechaniniai matuokliai su besisukančiais rotoriais dèl jų aukšto tikslumo ir patikimumo yra dažniausiai naudojami praktikoje šiems dydžiams matuoti, o jų teikiami duomenys teisiškai pripažistami.

Turbininiai matuokliai plačiai naudojami dideliems suslègtų dujų debitams matuoti. Tačiau ilgą laiką šie matuokliai buvo kalibruojami esant atmosferos slègiui. Dujų tankio didejjimas kylant dujų slègiui gerokai mažina dujų kinetinę klampą ir sudaro keblumų taikant kalibravimo rezultatus, gautus laboratorijoje esant atmosferos slègiui eksploatacijos sąlygomis. Nors pastaruoju metu jau keliose šalyse veikia įrenginiai matuokliams kalibruoti tekant darbinių parametrų dujoms, bet ši procedūra ir įrenginiai yra sudètingi ir brangūs. Todèl buvo tiriami iprastinio tipo vardinio dydžio DN400, 250 ir 150 bei 1,2; 0,75 ir $0,45 \mathrm{~m}$ ilgio turbininiai skaitikliai, turintys prieš rotorių skirtingų parametrų žiedinius ịtekejimo ruožus. Esant nuo 0,61 iki 3,5 $\mathrm{MPa}$ padidintam dujų slègiui, šie dujų matuokliai buvo bandomi ir kalibruojami užsienio laboratorijose (Pigsar arba Karlsruhe, Vokietija; Force, Danija). 
Sukieji kameriniai matuokliai (toliau - kameriniai) su slankiomis mentèmis labai plačiai naudojami skystojo kuro debitui ir kiekiui matuoti. Ju matavimo neapibrèžtis lemia skysčio pertekejjimai per plyšius tarp rotoriaus menčių, kurios sudaro atskiras kameras, ir korpuso. $\mathrm{Pa}$ grindinis šių matuoklių trūkumas - didelis jautris skysčio tekejjimo režimui ir skysčio tankio, klampos priklausomumas nuo skysčio rūšies, jo temperatūros ir slègio. Kameriniai matuokliai buvo tiriami 4 skirtingų skysčių srautuose kintant jų tankiui nuo 719 iki $838 \mathrm{~kg} / \mathrm{m}^{3}$ ir kinetinei klampai atitinkamai nuo $0,67 \cdot 10^{-6} \mathrm{iki}$ $5,5 \cdot 10^{-6} \mathrm{~m}^{2} / \mathrm{s}$.

Ne mažiau svarbios matuoklių veikimo principo ittakos matuojant mažus vandens srautus ir jais pernešamus šilumos kiekius. Todèl šioje srityje buvo atliekami tyrimai su vienasraučiais ir daugiasraučiais turbininiais, kameriniais ir ultragarsiniais bei magnetoindukciniais (elektromagnetiniais) mažų debitų matuokliais modeliuojant eksploatacijos metu atsirandančius trukdžius ir tiekimo / vartojimo nestabilumus.

Tai, kad sudettingos formos kanaluose srauto struktūra gerokai kinta, paskatino įsisavinti ir pletoti perspektyvius eksperimentinius tyrimo metodus, pagrịstus dalelių srautuose vizualizavimu ir neinvazinių matavimo metodų taikymu.

Eksperimentiniai ir skaitinio modeliavimo tyrimai buvo palyginami su tyrimais darbinemis sąlygomis ir rezultatais, gautais kitose laboratorijose.

\section{Tachometrinių debito matuoklių veikimas pulsuojančiame sraute}

\section{Universalus dinaminès paklaidos nustatymo}

metodas

Parengtas tachometrinių matuoklių inercijos laiko pastoviosios pagal atsaką ị staigų debito pokytị ìvertinimo metodas, skirtas iqvertinti laiko pastoviosios priklausomumą nuo pradinio, galinio ir perteklinio rotoriaus sukimosi dažnio bei jų dinaminès paklaidos priklausomumą nuo debito kitimo dèsnio, pulsacijų dažnio ir amplitudès bei matuoklio savybių, lemiančių jo inertiškumą [3-5]. Dinaminès paklaidos, kuri atsiranda pulsuojančiame sraute dèl matuoklio rotoriaus inercijos, formavimosi schema pateikta 1a pav. Srautui pulsuojant, matuoklio rodmenys greičiau artejja prie tikrosios debito vertès pastarajam didejjant, negu jam ma-

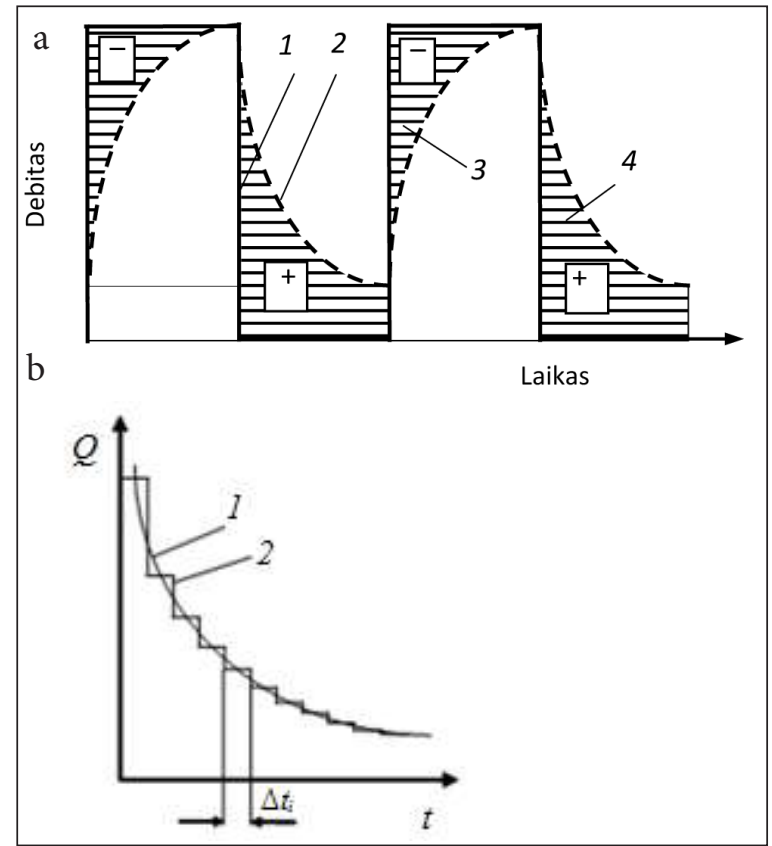

1 pav. Dinamines paklaidos formavimosi schema ir debito kitimo kreivès modeliavimas laiptuotu désniu: a) 1 - tikrasis debitas; 2 - debitas, atitinkantis matuoklio apsukas; 3 - neregistruojamas dujų kiekis; 4 - perviršinis registruojamas dujų kiekis; b) 1 - realus debito kitimas; 2 - modeliuojamas priklausomumas

žejant. Todèl matuoklio dinaminė paklaida visada turi teigiamą ženklą.

Metodas tinka matuoklio dinaminei paklaidai ịvertinti esant iqvairiems sudetingiems srauto pulsacijos désniams [6-8]. Tuo tikslu debito kitimo bėgant laikui kreive pakeičiama laiptuotu dèsniu (1b pav.) ir kiekviename laiko žingsnyje $\Delta t_{i}$ matuoklio rodmenims skaičiuoti taikoma eksperimentiškai nustatyta matuoklio atsako i̇ stačiakampi debito pokytị lygtis. Metodas leidžia atsisakyti iki šiol taikytos tradicinès matuoklio rotoriaus sukimosi diferencialios lygties su keliais sunkiai ir didele neapibrèžtimi nustatomais parametrais. Šių parametrų visuma pakeičiama vieninteliu parametru - rotoriaus sukimosi inercijos indeksu $(\tau)$, kartais vadinamu inercijos laiko pastoviaja, kuri gana lengvai nustatoma eksperimentiškai. Metodo taikymą riboja vienintelis reikalavimas - matuoklio rodmenų kitimo dèsnis turi būti reguliarus nuo pat proceso pradžios arba kitimo dèsnis turi būti žinomas visame jo kitimo intervale.

Matuoklio dinaminè paklaida pulsuojančiame sraute

$$
\delta=\left(Q_{v i d_{s k}}-Q_{v i d}\right) / Q_{v i d} ;
$$


čia: $Q_{v i d_{s k}}=\left(\sum Q_{s k_{i}}\right) / n$ - vidutinis debitas pagal matuoklio rodmenis; $Q_{\text {vid }}=\left(\sum Q_{i}\right) / n$ - vidutinis tikrasis debitas laikotarpiu $\Delta t_{i}$.

Kiekvienu laikotarpiu debitas iš matuoklio rodmenų apskaičiuojamas pagal priklausomumą:

$$
Q_{s k_{i}}=\omega_{i} / k_{i m p} ;
$$

čia: $k_{i m p}$ - matuoklio impulso verte $\mathrm{imp} / \mathrm{m}^{3}$; $\omega_{i}$ - matuoklio rotoriaus sukimosi dažnis i-tuoju laiko momentu, kuris gaunamas iš eksperimentiškai nustatyto priklausomumo:

$$
\frac{\omega_{s k_{g a l}}-\omega_{s k_{p r}}}{\omega_{i}-\omega_{v_{i}}}=-\frac{t_{g a l}-t_{p r}}{\tau} ;
$$

čia: $\tau$ - laiko pastovioji; $\omega$ - sukimosi dažnis; $t$ - laikas; indeksai $g a l$ ir $p r$ - atitinkamai pulsacijos laikotarpio pabaigoje ir pradžioje.

Laiko pastovioji buvo nustatoma dviem metodais, laikant ją pastoviu dydžiu atsako metu, bet priklausantị nuo rotoriaus inercijos parametrų ir debito, arba laikant ją kintamuoju dydžiu [4, 9], apskaičiuojamu pagal priklausomumą:

$$
\tau=-\frac{1}{a_{1}+a_{2} t+\ldots+a_{6} t^{5}}
$$

čia: $a_{i}$ - polinomo koeficientai, gauti aproksimuojant tiriamojo matuoklio eksperimentiškai išmatuotus atsakus bėgant laikui; $t$ - laikas.

Eksperimentiniai tachometrinių matuoklių tyrimai atlikti panaudojant specialiai šiuo tikslu sukurtą ịrenginị, kuris ịgalina imituoti staigų debito pokyti tiriamajame matuoklyje ir išmatuoti jo atsaką. Tyrimams panaudoti skirtingų tipų matuokliai: turbininis ir sukusis kamerinis debitmačiai bei kaušelinis vejjo greičio matuoklis [10].

Išanalizavus eksperimentinių tyrimų rezultatus nustatyta, kad matuoklių laiko pastovioji kinta atsako proceso metu, ir šis kitimas iš esmès yra netiesinis. Vidutiné laiko pastoviosios vertè yra didesnè tuo atveju, kai debito pokytis yra didèjantis, nei kai debito ar greičio pokytis yra mažèjantis. Laiko pastoviosios verte pradeda didèti, kai galinè dažnio vertè artèja prie apatinés matuoklio matavimo ribos. Galinei debito vertei artejjant prie 0 , laiko pastoviosios verte pradeda augti eksponentiškai. Nustatyta, kad pradine debito vertè neturi ịtakos laiko pastoviąjai, ir visų trijų tipų matuoklių inercijos laiko pastoviosios priklauso nuo galinio rotoriaus sukimosi dažnio vertès bei yra jam atvirkščiai proporcingos.

\section{Turbininiu duju matuokliu dinamine paklaida}

Turbininių matuokliu atsako ir dinaminès paklaidos tyrimai atlikti oro debitui pulsuojant pagal paprastus (stačiakampio, kosinuso bei trikampio), taip pat pagal sudetingus (artimus pasitaikantiems praktikoje) dèsnius ir jų rezultatai apibendrinti [11] darbe. Nustatyta, kad visais atvejais, esant žemam $(0,01-0,05) \mathrm{Hz}$ dažniui, matuoklio inertiškumas praktiškai nepasireiškia, matuoklis spejja atsekti net staigų srauto pokyti ir jo rodmenys labai mažai skiriasi nuo tikrụjų debito verčiuc. Debito pulsacijos dažniui padidejjus iki $0,5 \mathrm{~Hz}$, inertiškumas pasireiškia ženkliai, bet matuoklis reaguoja ị debito kitimą esant net mažai amplitudei.

Dažniui padidejus iki $1 \mathrm{~Hz}$, matuoklis nespèja reaguoti i debito pokyčius, jo rodmenys praktiškai tampa pastovūs ir didesni už vidutinę pertekančio debito vertę.

Taigi, dažniui didejjant, dinaminè paklaida auga iki tam tikros ribinès vertès, kuri priklauso nuo srauto pulsacijų dėsnio ir nuo pulsacijos amplitudès. Iki $1 \mathrm{~Hz}$ pulsacijų dažnio matuoklių rodmenų kitimas visais atvejais arteja prie kosinuso désnio. Matuoklio rodmenų maksimumas ir minimumas yra pasislinkę bègant laikui debito maksimumo ir minimumo atžvilgiu ir pasiekiami tada, kai matuoklio rodmuo yra lygus momentiniam tikrajam debitui. Esant stačiakampiam srauto pulsacijų dèsniui, matuoklio rodmenys kinta pagal sudètingą eksponentini dèsni. Rodmenų maksimumas ir minimumas pasiekiami srauto staigaus kitimo momentu.

Nustatytas dinaminès paklaidos priklausomumas nuo srauto pulsacijų dažnio esant stačiakampiam dèsniui ir skirtingoms pulsacijų amplitudèms parodytas 2 pav. Analogiški rezultatai gauti debitui pulsuojant pagal kitus nagrinètus désnius.

Kamerinių dujų debito matuoklių atsako $\mathfrak{i}$ srauto pulsacijas priklausomumai yra analogiški turbininių matuoklių atsako priklausomumams, tačiau šių matuoklių registruojamas debito kitimas seka jų rotoriaus apsukų dažnio pokyčius, todèl matavimo paklaidas iš esmès lemia tik pertekejjimai pro plyšius tarp rotorių ir korpuso, kuriuos mažai veikia srauto pulsacijos. 

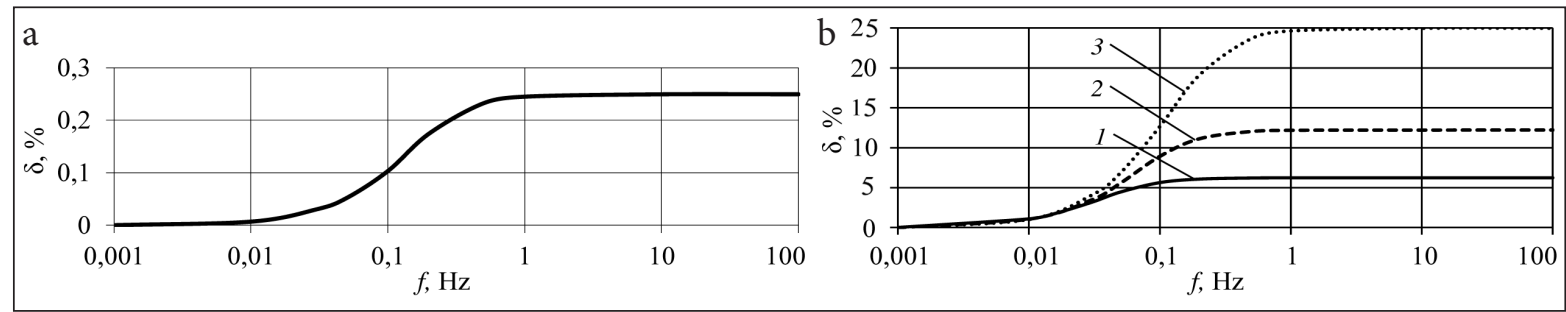

2 pav. Dinaminès paklaidos priklausomumas nuo srauto pulsacijų dažnio esant skirtingoms pulsacijų amplitudems $(\Delta \bar{Q})$ ir stačiakampiam jos kitimo dessniui, kai $\tau=1,054 \mathrm{~s}$ : a $-\Delta \bar{Q}=0,05 ; b-1,2,3$ - atitinkamai $\Delta \bar{Q}=0,25 ; 0,35$ ir 0,5

\section{Kaušeliniu anemometru dinaminè paklaida}

Kitaip nei turbininiai dujų debito matuokliai, mechaniniai oro greičio matuokliai veikia atviro lauko sąlygomis, dažnai esant stipriam turbulentiškumui, kurio verte gali siekti kelias dešimtis procentų. Vejo greičio pulsacijos susideda iš atskirų ịvairių dažnių ir amplitudžių nepriklausomų trikampio formos impulsų. Siekiant sumodeliuoti tokias sudètingos formos vejo greičio pulsacijas būtina apibrèžti šiuos parametrus $[10,11]$ :

- minimalią $v_{\text {min }}$ ir maksimalią $v_{\text {max }}$ greičio vertes (amplitudes);

- vèjo greičio pulsacijų dažnį;

- koeficientą $k_{v}\left(k_{v} \geq 0\right)$, kuris apibrěžia greičio pulsacijų amplitudès mažèjimo spartą (mažejimas vyksta pagal aritmetinę progresiją) viename pulsacijos cikle. Kai $k_{v}=0$, greičio amplitudès verte pulsacijoje nekinta. Didèjant šio parametro vertei $\left(k_{v}>0\right)$, pulsacijų amplitudžių vertè pulsacijoje mažèja sparčiau;

- koeficientą $k_{t}\left(k_{t} \geq 0\right)$, kuris apibrèžia greičio pulsacijų dažnio mažejimo spartą (mažèjimas taip pat vyksta pagal aritmetinę progresiją) viename pulsacijos cikle. Kai $k_{t}=0$, greičio pulsacijos dažnio vertè pulsacijoje nekinta. Didejjant šio parametro vertei $\left(k_{t}>0\right)$, pulsacijų dažnis pulsacijoje mažèja sparčiau;

- pikų skaičių viename impulse.

Kaušelinio oro greičio matuoklio atsakui ir dinaminei paklaidai skaičiuoti panaudotas turbininiams matuokliams taikytas metodas, išskyrus tai, kad turbininiams matuokliams inercijos laiko pastovioji buvo priimama priklausanti tik nuo galinio debito arba galinio sukimosi dažnio. Greičio matuoklio atveju buvo vertinama ne tik galinio, bet ir perteklinio dažnio įtaka.

Esant mažiems $\leq 0,01 \mathrm{~Hz}$ pulsacijų dažniams, kaušelinio oro greičio matuoklio inercija, kaip ir turbininių debito matuoklių atveju, nepasireiškia.
Padidèjus pulsacijų dažniui, matuoklis nebespèja sekti tikrąsias oro greičio vertes, ir jo rodmenys didèjant dažniui tampa pastovūs bègant laikui, bet didesni nei vidutinè greičio vertè. Analogiški rezultatai gauti skirtingiems koeficientų $k_{V}$ ir $k_{t}$ deriniams, taip pat esant skirtingoms $v_{\max }$ ir $v_{\min }$ vertems.

Dinaminès paklaidos ir matuoklio atsako skaitinio modeliavimo rezultatai pulsuojančiame sraute, esant parametrams $k_{v}=(0,1 ; 0,5 ; 1)$ bei $k_{t}=0,5$, pateikti 3 pav. Parodytų priklausomumų pobūdis toks pat, kaip ir turbininių matuoklių atveju.

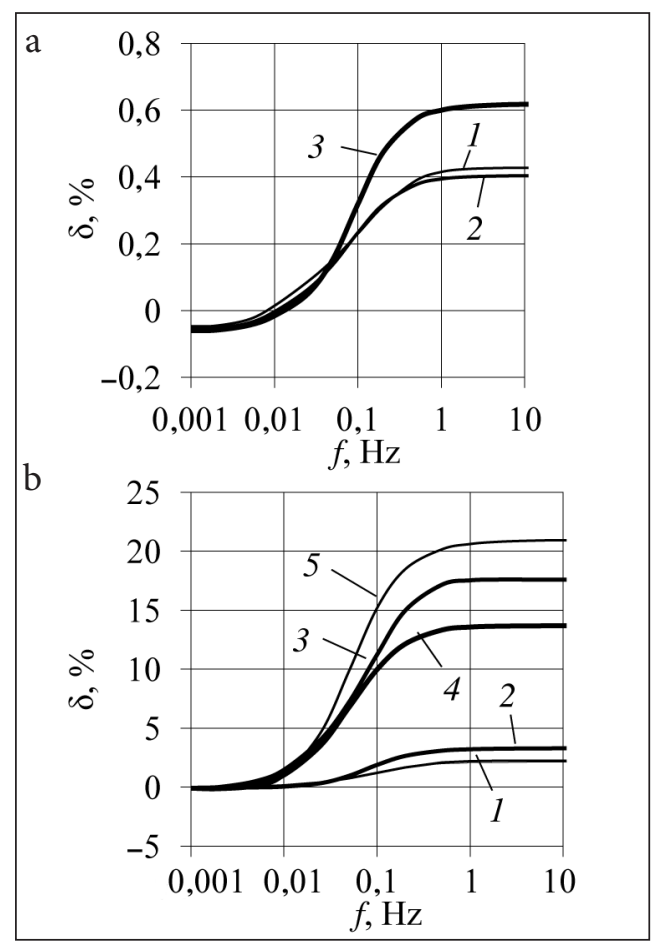

3 pav. Kaušelinio anemometro dinaminès paklaidos modeliavimo rezultatai, kai $k_{t}=0,5: a-v_{\max }=5 \mathrm{~m} / \mathrm{s}$ ir $v_{\text {min }}=3,5 \mathrm{~m} / \mathrm{s} ; 1-3$ - atitinkamai $k_{v}=0,1 ; 0,5$ ir 1; $b-v_{\text {max }}=10 \mathrm{~m} / \mathrm{s} ; 1,2-$ atitinkamai $v_{\text {min }}=7,5 \mathrm{~m} / \mathrm{s}$, $k_{v}=0,5$ ir $1 ; 3-5-$ atitinkamai $v_{\min }=1 \mathrm{~m} / \mathrm{s}, k_{v}=0,1$; 0,5 ir 1 
Matuoklio rodmenų santykinès svyravimo amplitudès kitimo pobūdis atitinka dinaminès paklaidos kitimo pobūdị, bet kitimų kryptys yra priešingos.

Tačiau kitaip nei turbininių debito matuoklių, dinaminès paklaidos ir nedimensinès amplitudès kreivès išsisluoksniuoja esant skirtingoms koeficiento $k_{v}$ vertėms. Be to, atskiros kreivès susikerta. Tai paaiškinama vidutinio greičio įtaka inercijos laiko pastoviajai. Kaušelinių oro greičio matuoklių atsako ir dinaminès paklaidos kitimo pobūdị lemia didžiausia ir mažiausia oro greičio vertès, jo pulsacijų dažnis ir pulsacijų dažnio bei amplitudès kitimo sparta. Nustatyta, kad greičio pulsacijų dažnio ittakos kaušeliniams ir turbininiams matuokliams yra analogiškos, tačiau esant mažesniems nei $0,01 \mathrm{~Hz}$ dažniams ir nereguliariam oro greičio pulsacijų dažnio ir amplitudès kitimui, kaušelinių matuoklių dinaminè paklaida tampa neigiama.

\section{Tachometrinių srauto matuoklių veikimas kintant fluidų klampai}

Kaip nurodyta skyriuje „Tyrimo objektai ir tikslai“, buvo tiriamas kamerinių ir turbininių matuoklių matavimo rezultatų priklausomumas nuo skysčiu ir dujų klampos siekiant nustatyti universalius paklaidų kitimą lemiančius parametrus.

\section{Skysčio klampos įtaka kameriniu matuokliu paklaidoms}

Nustatytas universalus kamerinių matuoklių paklaidu priklausomumas nuo $\mathrm{Re}_{D}$, kuriame būdinguoju geometriniu parametru priimtas itekéjimo angos skersmuo, pateiktas 4 pav. [12, 13].
Matyti, kad paklaidų kreivès turi dominuojantị piką, iki kurio paklaidos išsisluoksniuoja dèl mechaninès trinties ir hidrodinaminių jègų, sukeliamų skysčio klampos, poveikių.

Didejjant skysčio debitui ir $\mathrm{Re}_{D}$, paklaidos kinta neigiamų jų reikšmių link. Tai lemia didèjantis sukamųjų jègų momentas, dèl kurio mechaninès trinties ir klampos jejgų stabdantysis poveikis santykinai mažeja, kol pasiekiama sukamųjų ir stabdančiųjų jègų pusiausvyra. Skysčio klampai mažejjant, paklaidų pikas slenka link didesnių $\operatorname{Re}_{D}$ reikšmių ir jo padètis sutampa su esminiu slègio nuostolių kitimo dėsningumu pokyčiu, kurị lemia tekejimo matuoklio kanale perejimas iš laminarinio režimo ił turbulentinị. Vykstant turbulentiniam tekejjimui, paklaidų kitimas tampa universalaus pobūdžio, ir paklaidos artèja prie tam tikros asimptotinès reikšmès, kai $\mathrm{Re}_{D} \approx 10^{6}$. Pastarasis reiškinys rodo, kad esant tokiems $\operatorname{Re}_{D}$ tekejjimo struktūrą lemia turbulentinè klampa, ir matuoklių rotorius sukančiosios ir stabdančiosios jègos arteja prie pusiausvyros.

\section{Oro (duju) klampos ịtaka turbininiu matuokliu paklaidoms}

5 pav. pateiktos turbininių matuoklių paklaidos esant atmosferos slègiui, atsižvelgiant $\underset{\mathfrak{i}}{\mathrm{Re}_{\mathrm{Dh}}}$, kuriame būdinguoju geometriniu parametru priimtas žiedinio kanalo prieš matuoklio rotorių hidraulinis skersmuo [12, 14]. Galima daryti išankstinę prielaidą, kad rezultatų sklaidą pirmiausia lemia skirtingi matuoklių konstrukcijos tipai ir dydžiai. Be to, prie mažų $\operatorname{Re}_{D h}$, kurie pasiekiami

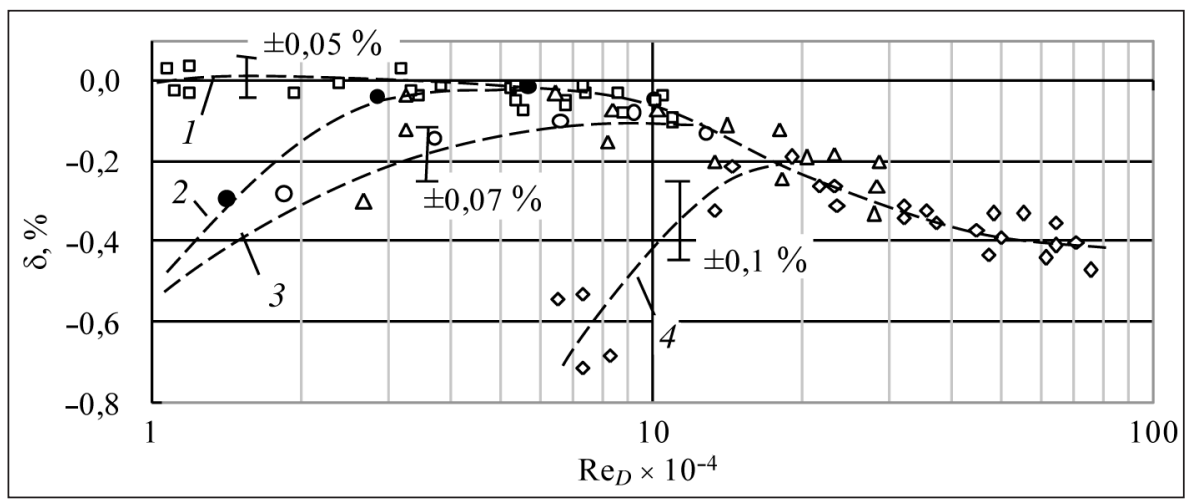

4 pav. Tiriamujų kamerinių matuoklių paklaidų priklausomumas nuo $\mathrm{Re}_{D}$ skirtingos kinetinės klampos skysčiuose: DN100 matuoklis: 1 - dyzelinas $\left(\bar{v}=4,6 \cdot 10^{-6} \mathrm{~m}^{2} / \mathrm{s}\right) ; 3$ - Exxsol D80 ir aviacinis žibalas $\left(\bar{v}=(2 \pm 0,3) \cdot 10^{-6} \mathrm{~m}^{2} / \mathrm{s}\right) ; 4$ - benzinas $\left(\bar{v}=0,73 \cdot 10^{-6} \mathrm{~m}^{2} / \mathrm{s}\right)$; DN65 matuoklis: 2 - Exxsol D80 žibalas $\left(\bar{v}=2,3 \cdot 10^{-6} \mathrm{~m}^{2} / \mathrm{s}\right)$ 


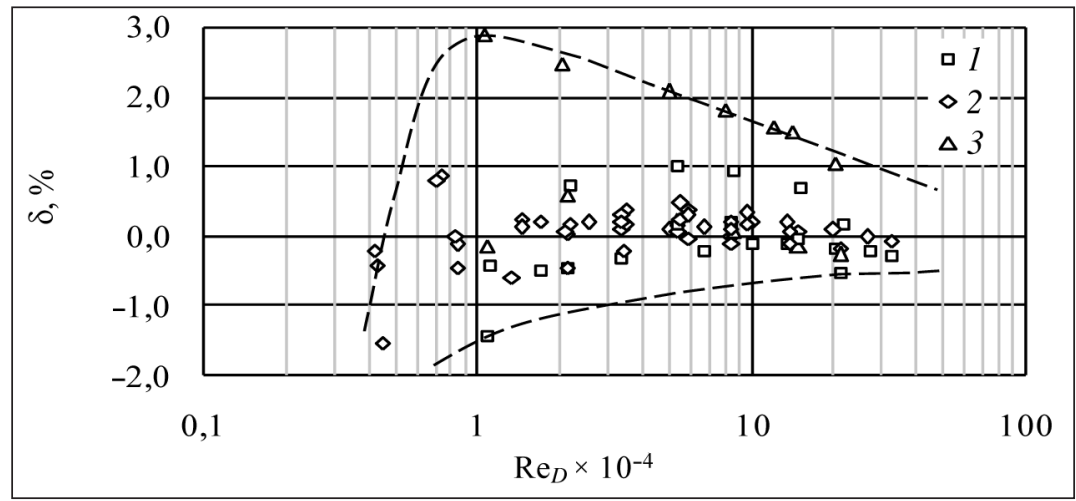

5 pav. Tiriamujų turbininių matuoklių paklaidos esant atmosferos slègiui $\left(\bar{v}=15 \cdot 10^{-6} \mathrm{~m}^{2} / \mathrm{s}\right)$ : 1 - kreivès su vienu pagrindiniu piku; 2 - su 2 pikais arba su netolygiu artejimu prie pagrindinio piko; 3 - be pagrindinio piko

esant atmosferos slègiui, paklaidų kitimą smarkiai veikia rotorių sukimąsi stabdančiosios mechaninès trinties ir klampos jègos, santykinai mažas sukimo momentas, žiedinio įtekèjimo kanalo forma ir matmenys, kurie lemia atitekančio srauto greičio pasiskirstymą, taip pat kiti veiksniai, susiję su matuoklio konstrukcijos keitimais kalibravimo kreivèms linearizuoti. Tirtujjų turbininių matuoklių paklaida siekia nuo 1,5 iki $3 \%$, esant atmosferos slégiui ir atitinkamai mažiems $\operatorname{Re}_{D h}$.

Tačiau ši sklaida sumažèja iki $\pm 0,5 \%$, kai $\operatorname{Re}_{D h}$ padideja iki $\sim 4 \cdot 10^{5}$. Trumpai tai galima paaiškinti, kaip ir kamerinių matuoklių atveju, $\mathrm{Re}_{D h}$ poslinkiu link didesnių jo verčių, kurioms esant mažeja veiksnių, reikšmingų prie mažų $\mathrm{Re}_{D h}$, poveikis ir išsilygina likusių veiksnių poveikis, kai artëjama didelių link $\mathrm{Re}_{D h}$.

Analizé rodo, kad ši paklaidų sklaida yra dèsninga [15]. Tuo tikslu 6 pav. pateikti normalizuotų paklaidų priklausomumai nuo parametro $R e_{D h} / k$ :

$$
\Delta=\frac{\left(\delta-\delta_{\min }\right)}{\left(\delta_{\max }-\delta_{\min }\right)}=\left(\frac{\mathrm{Re}_{D h}}{k}\right) ;
$$

čia: $\delta_{\min }, \delta_{\max }-$ mažiausia ir didžiausia matuoklio paklaida, $\% ; k$ - koeficientas, $\mathrm{m}$.

Pastaba. Šiuo atveju $k$ koeficientas ịvestas siekiant suartinti skirtingo dydžio matuoklių paklaidų kreives, nes vienas $\operatorname{Re}_{D h}$ neįvertina, kad turbininis matuoklis turi besisukantị rotorių ir sukamasis momentas priklauso nuo menčiu aukščio ir jų nuotolio nuo rotoriaus ašies bei kitų veiksnių. Pirmajam priartejimui prie apibendrintos kreivés priimta, kad $k$ yra lygus atstumui nuo mentés centro iki rotoriaus ašies.
6 pav. matome, kad galima išskirti mažiausiai 3 skirtingas paklaidų kreivių formas. Pirmasis paklaidų tipas (1) turi vieną pagrindinị piką $\operatorname{Re}_{D h} / k=(5-8) \cdot 10^{5}$ zonoje. Kaip skysčių kamerinių matuoklių atveju, pagrindinis pikas dalija matuoklio matavimo intervalą i 2 dalis - pirmoje dalyje matuoklis veikia esant mažiems $\mathrm{Re}_{D h}$ ir jam itakos turi visi anksčiau nurodyti veiksniai. Kai $\operatorname{Re}_{D h} / k>8 \cdot 10^{5}$, matuoklis veikia esant turbulentiniam tekejimo režimui ir nepriklausomai nuo skysčio fizikinès klampos bei mechaninių veiksnių. Todèl paklaidų kreivès ịgauna panašumą.

Antrajam paklaidų tipui (2) būdingas pirmasis paklaidų pikas, esantis mažesnių $\mathrm{Re}_{D h} / k \leq 2 \cdot 10^{5}$ zonoje. Jo atsiradimą lemia srauto turbulizacija itekéjime arba matuokliu konstruktorių taikomos priemonès sumažinti stabdančiųjų mechaninių ir klampos jëgų poveiki, padidinti sukamąji momentą išnaudojant greičio pasiskirstymo ypatumus pradiniame žiediniame kanale prieš matuoklio rotorių, kuriame vyksta pereinamasis tekejjimo režimas. Greičio ir jo pulsacijų kitimo désningumai pereinamuosiuose tekèjimo režimuose buvo nagrinejjami darbuose $[16,17]$ ir iš dalies patvirtina daromas prielaidas. Be to, tokioje sudètingoje sistemoje negalima atmesti ženklios srauto atitrūkimo nuo menčių ir su tuo susietų rezonansinių reiškinių ittakos. Visi šie poveikiai gali būti traktuojami kaip hidrodinaminiai srauto trukdžiai, kurie sukelia srauto turbulizavimą ir paklaidų piko atsiradimą esant mažiems $\mathrm{Re}_{D h} / k$. Kadangi tai atsitinka mažų $\mathrm{Re}_{D h} / k$ zonoje, visiškai išsivystęs turbulentinis tekèjimas nesusidaro. Banguotas paklaidų kitimas prieš pagrindini paklaidų piką parodo išliekantị srauto jautrị ịvairiems trukdžiams. Pagrindinis paklaidų 


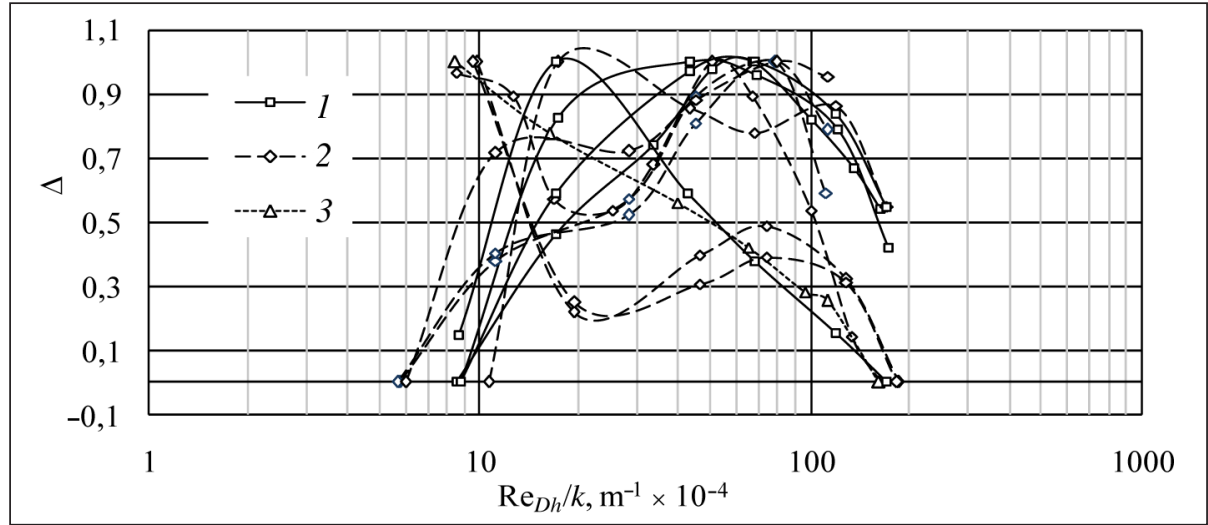

6 pav. Turbininių matuoklių normalizuotų paklaidų kitimo kreivių palyginimas: 1 - paklaidų kreivės su vienu pagrindiniu piku; 2 - su 2 pikais arba su netolygiu artèjimu prie pagrindinio piko; 3 - be pagrindinio piko

pikas gali susidaryti arba jis gali būti sunkiai pastebimas, jei srautas smarkiai turbulizuotas.

Trečiajam paklaidų tipui (3) būdingi pastarieji požymiai, kai paklaidų kitimo kreivè išlaiko išvystytam turbulentiniam tekejjimui būdingą formą, kol pasiekiama pagrindinio paklaidos piko zona.

Svarbu atkreipti dèmesị i tai, kad paklaidų kreivès lūžių taškai yra tiesiogiai susieti su esminiais sukamųjų ir stabdančiųjų jègų santykio pokyčiais ir yra apibrèžtose vietose: pagrindinis pikas $\mathrm{Re}_{D h} / k=(5-8) \cdot 10^{5}$ zonoje; pirmas pikas arba minimumas - (1-3) $10^{5}$ zonoje. Paklaidų kreivių tarp lūžio taškų polinkis taip pat yra ganètinai informatyvus. Taigi analizuojant paklaidų kreivių formą galima numatyti matuoklio veikimo režimą ir padidinto srauto slégio poveikị matuoklio paklaidoms.

7 pav. pateiktas turbininių matuoklių paklaidų priklausomumų palyginimas esant atmosferos ir padidintam slègiui. Matyti, kad padidinus slègi turbininio matuoklio paklaidos priartėja prie lygmens, būdingo jų lygiui, kai atmosferos slègis ir $\operatorname{Re}_{D h} \sim 4 \cdot 10^{5}$ (žr. 5 pav.). Tai rodo, kad didèjant slègiui didžiausias paklaidų pokytis vyksta esant mažiems $\operatorname{Re}_{D h}$, nes matuoklio mažiausios neigiamos paklaidos dèl srauto tankio ir sukamojo momento didejimo pakinta link teigiamų jų verčių, o pikinè vertè mažèja, nes padidejus $\mathrm{Re}_{D h}$ turbulentinis tekejimo režimas pasiekiamas greičiau.

Jei esant atmosferos slėgiui paklaidų kitimas atitinka jų kitimo pobūdi prie turbulentinio tekèjimo režimo, tokia pat paklaidų kitimo tendencija išlieka padidejjus slègiui. Tai patvirtina, kad tokiu atveju visame intervale galioja panašumo pagal $\mathrm{Re}_{D h}$ principas, nes paveikiujų veiksnių itaka turbulentiniame režime išnyksta.

Apibendrinant gautus rezultatus galima daryti išvadą, kad pagal turbininio matuoklio paklaidų kreives, nustatytas esant atmosferos slègiui, galima

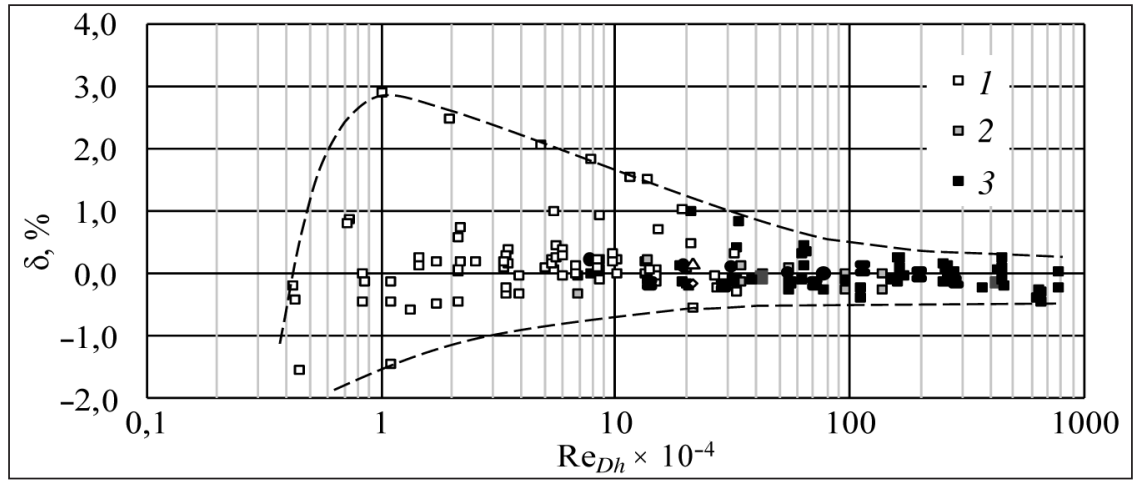

7 pav. Tiriamujų turbininių matuoklių paklaidų esant atmosferos ir padidintam slegiui palyginimas: 1 - atmosferos slègis, $\bar{v}=15 \cdot 10^{-6} \mathrm{~m}^{2} / \mathrm{s} ; 2$ - slègis $0,61 \mathrm{MPa}, \bar{v}=2,74 \cdot 10^{-6} \mathrm{~m}^{2} / \mathrm{s} ; 3$ - slègis $3,5 \mathrm{MPa}$, $\bar{v}=0,46 \cdot 10^{-6} \mathrm{~m}^{2} / \mathrm{s}$ 
pakankamu tikslumu prognozuoti paklaidų pokyčius matuokliui veikiant, kai slègis yra padidintas. Siekiant užtikrinti tokios prognozès patikimumą, būtina kalibruojant nustatyti matuoklio paklaidų kreivę, kai atmosferos slègis yra kiek galima platesniame $\mathrm{Re}_{D h}$ intervale. Labai svarbu tai atlikti esant mažiems $\mathrm{Re}_{D h}$ ir $\mathrm{Re}_{D h}>10^{5}$, kai tekèjimas pereina i turbulentinį režimą, ir paklaidos pradeda artèti prie nuolatinès asimptotinès vertès, kuri beveik nekinta didèjant slègiui. Šie rezultatai gerai koreliuoja su priklausomumu tarp matuoklio faktoriaus K, išreiškiančio apsukų impulsui tenkantị pertekejjusio skysčio tūrị, ir parametro $\left(\mathrm{Hz} /(v)^{-}\right)$.

8 pav. pateiktas kameriniu (a) ir turbininių (b) matuoklių paklaidų skysčių ir oro (dujų) srautuose palyginimas. Matyti, kad nežiūrint ị kamerinių ir turbininių matuoklių matavimo principų skirtumus, panašumas pagal Re skysčiui ir dujoms tekant turbulentiškai tachometrinių matuoklių kanaluose išlieka. Tam tikri skirtumai gali būti paaiškinami neadekvačiu būdingojo geometrinio dydžio Re skaičiuje parinkimu dèl sudètingos kanalų geometrijos ir skirtingos rotorių formos bei jų sąveikos su matuoklio korpuso sienelèmis. Tačiau stebimas priklausomumų panašumas leidžia daryti išvadą, kad smarkiai turbulizuotame sraute atitrūkimo ir išcentrinių jègų poveikiai suvienodejja, o didelio mastelio turbulentinių trukdžiu poveikis tekẻjimui arti sienelès yra silpnas.
Skyriuose „Tachometrinių debito matuoklių veikimas pulsuojančiame sraute“ ir "Tachometrinių srauto matuoklių veikimas kintant fluidų klampai“ pateikti tyrimo rezultatai buvo panaudoti kuriant oro (dujų), vandens, naftos ir naftos produktų tūrio bei debito valstybinius etalonus, taip pat užtikrinant šių dydžių matavimų Lietuvoje sietị su Europos šalių nacionalinių institutų teikiamais matavimų tikslumais.

\section{Kiti vykdyti MTEP darbai ir jų rezultatyvumas}

Kuriant etalonų techninę bazę ir atsižvelgus ị kiekvienos matavimo srities ypatumus buvo taip pat atlikti kiti reikšmingi srautų dinamikos tyrimai ir jų rezultatų tiesioginiai taikymai:

- ivairios klampos plèvelių ant vertikalaus cilindrinio paviršiaus tekejjimo dinamikos tyrimai $[18,19]$, padejję sukurti varpo tipo etaloną oro (dujų) tūrio ir debito nuo $0,016 \mathrm{iki} 16 \mathrm{~m}^{3} / \mathrm{h}$ vertèms su neapibrèžtimi iki $0,13 \%$ atkurti, kurio analogai vèliau pagaminti ir įdiegti penkiose Lietuvos dujų ūkio laboratorijose ir dviejose Moldovos dujų ūkio laboratorijose;

- kritinių tūtų veikimo dinamikos tyrimai, pagal kuriuos sukurtas etalonas oro (dujų) tūrio ir debito nuo $5,7 \mathrm{iki} 308 \mathrm{~m}^{3} / \mathrm{h}$ vienetams su neapibrežtimi $0,16 \%$ atkurti, kurio vienas analogas pagamintas ir įdiegtas Lietuvos dujų ūkyje, o kitas Maskvos (Rusija) dujų matuoklių gamykloje;

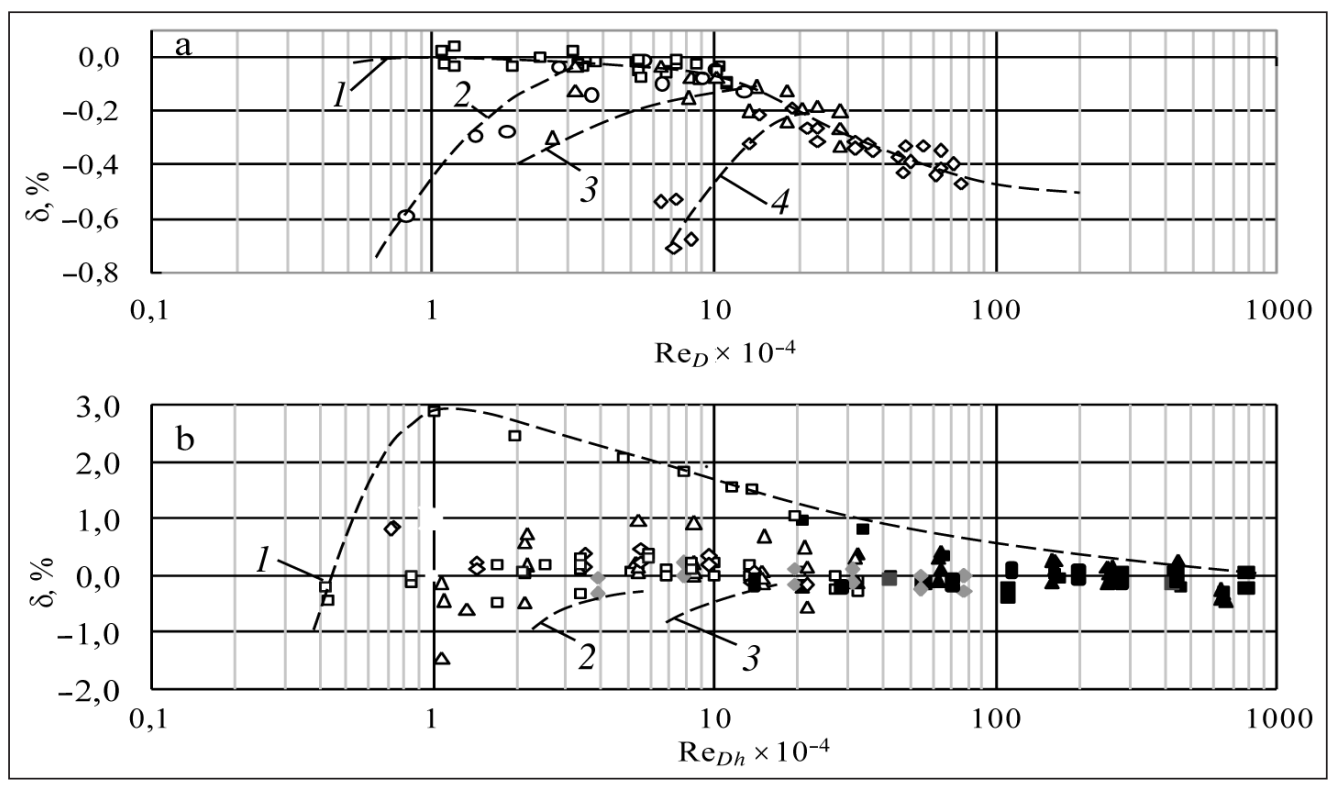

8 pav. Kamerinių ir turbininių matuoklių paklaidų kreivių palyginimas, atsižvelgus į $\operatorname{Re}_{D}$ ir $\operatorname{Re}_{D h}: \mathrm{a}$-kamerinis matuoklis; 1, 2, 3 ir 4 žymejjimai tokie pat, kaip 4 pav.; b - turbininis matuoklis; 1, 2 ir 3 žymèjimai kaip ir 5 pav. 
- įvairių greičio matuoklių aptekèjimo ir tekèjimo siaurèjančiose tūtose ir kanaluose kintant tekejjimo režimams dinamikos tyrimai $[20,21]$. Jie padejo sukurti etaloną oro (dujų) greičio nuo 0,05 iki $60 \mathrm{~m} / \mathrm{s}$ vertèms su neapibrěžtimi $(8,0-0,45) \%$ atkurti, kuris laipsniškai buvo tobulinamas įdiegiant neinvazinius ultragarsị ir lazerini greičio matuoklius;

- įvairių tipų (vienasraučių ir daugiasraučių turbininių, kamerinių, ultragarsių bei magnetoindukcinių) mažų debitų matuoklių matavimo tikslumo veikiant ịvairiems trukdžiams tyrimai [22-24], kurie igalino nustatyti vandens ir šilumos tiekimo / vartojimo ne balanso priežastis bei pateikti rekomendacijas apskaitai gerinti.

\section{Tekẻjimo mikrokanaluose su struktūrizuotais} paviršiais tyrimų plètra

Tyrimų plètrą paskatino šie veiksniai:

- poreikis ir galimybé išsamiau ištirti sudètingu tekejjimų, kurie vyksta sudetingos formos kanaluose ir kuriuos lydi srauto atitrūkimo reiškiniai, struktūrą;

- struktūrizuoto paviršiaus įdubos / kavernos gali būti tinkamu modeliu tirti tekèjimo išsišakojimo (bifurkacijos) procesus ir sūkurinių struktūrų tarpusavio sąveikos mechanizmą;

- srauto tyrimai mažo skersmens sudètingos formos kanaluose teikia žinių apie srauto dinamiką ir tekèjimo struktūrą, kurios gali būti taikomos sprendžiant inžinerines problemas, susijusias su srautų maišymosi intensyvinimu mikroreaktoriuose ir mikroelektromechaninèse sistemose bei mažuose šilumokaičiuose. Taip pat visiškai realus šio metodo ir rezultatų taikymas tiriant kraujo tekejjimo dinamiką širdies ir kraujagyslių sistemoje, trombų ir aneurizmų susidarymo kraujagyslèse problemas.

Eksperimentiniai tyrimai atliekami naudojant įsisavintą dalelių sraute vizualizacijos sistemą. Iki šiol eksperimentai vykdyti stačiakampio (artimo kvadratui) skerspjūvio kanaluose, kurio sienelès lygios arba jose suformuotos pereinamojo ir atvirojo tipų kavernos, kaip parodyta 9 pav. $[12,13]$.

Tiesiame kvadratinio skerspjūvio kanale (9a pav.) atliktais greičio pasiskirstymo tyrimais [25] patvirtinta metodo teikiamų rezultatų koreliacija su žinomais désningumais, susietais su pradinio ruožo ilgiais ir greičio pasiskirstymu kintant tekejjimo režimui nuo laminarinio iki turbulentinio, bei įtèkio geometrija. Nustatyta, kad tekejjimo dinamika tokio skersmens kanaluose iš esmès atitinka dèsningumus, stebimus ịprastinio dydžio kanaluose, ir skaitinio modeliavimo rezultatus, taikant turbulentiškumo modelį, pagrịstą Reinoldso ittempimų lygtimi.

Mikrokanale su pereinamojo tipo kavernomis [26] (kavernos ilgio ir gylio santykis $L / h_{1} \approx 10$ ) (9b pav.), nustatyti tekejjimo režimai, kuriems esant atitrūkęs nuo atbulinès kavernos sienelès srautas prisijungia prie kavernos dugno ir suformuoja recirkuliacinio tekejjimo zoną, kurios ilgis beveik tiesiškai didejja didejjant $\operatorname{Re}_{D h}$ (10 pav.). Pasiekus kavernos viduri prisijungiantis srautas dèl priekinès kavernos sienelès poveikio atkeliamas nuo dugno, ir kaverną užpildo lètos cirkuliacijos kontūras. Pasiekus turbulentini tekejjimo režimą, dèl padidèjusio turbulentinio maišymosi vèl stebimas prisijungimas prie kavernos dugno, bet recirkuliacinio tekejjimo zonos struktūra iš esmès pakinta. Vykstant turbulentiniam tekejjimui kanalu, recirkuliacinejje zonoje stebimi 2 pagrindiniai sūkuriai, kurių vienas prie atbulinès sienelès ir kitas tarp šio sūkurio ir prisijungimo taško. Šie sūkuriai didèdami pasiekia kavernos viršų ir atitrūksta. Toks procesas periodiškai pasikartoja iš naujo. Tai patvirtina teoriniai sprendiniai bégant laikui. Kaip matyti 10 pav., eksperimentiškai nustatytas vidutinis recirkuliacinès zonos ilgio kitimas gerai koreliuoja su skaitinio modeliavimo, naudojant Spallart-Almaras ir Reinoldso itempi$\mathrm{mų} \mathrm{(RSM)} \mathrm{modelius} \mathrm{turbulentiniam} \mathrm{maišymuisi}$

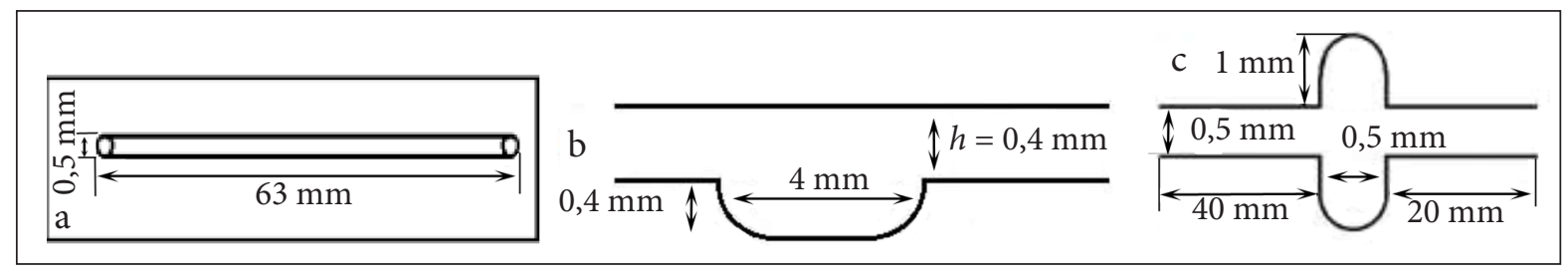

9 pav. Tiriamujų mikrokanalų schemos: a - tiesus kanalas; $b$ - kanalas su pereinamojo tipo kavernomis; $c$ - kanalas su atvirojo tipo kavernomis 


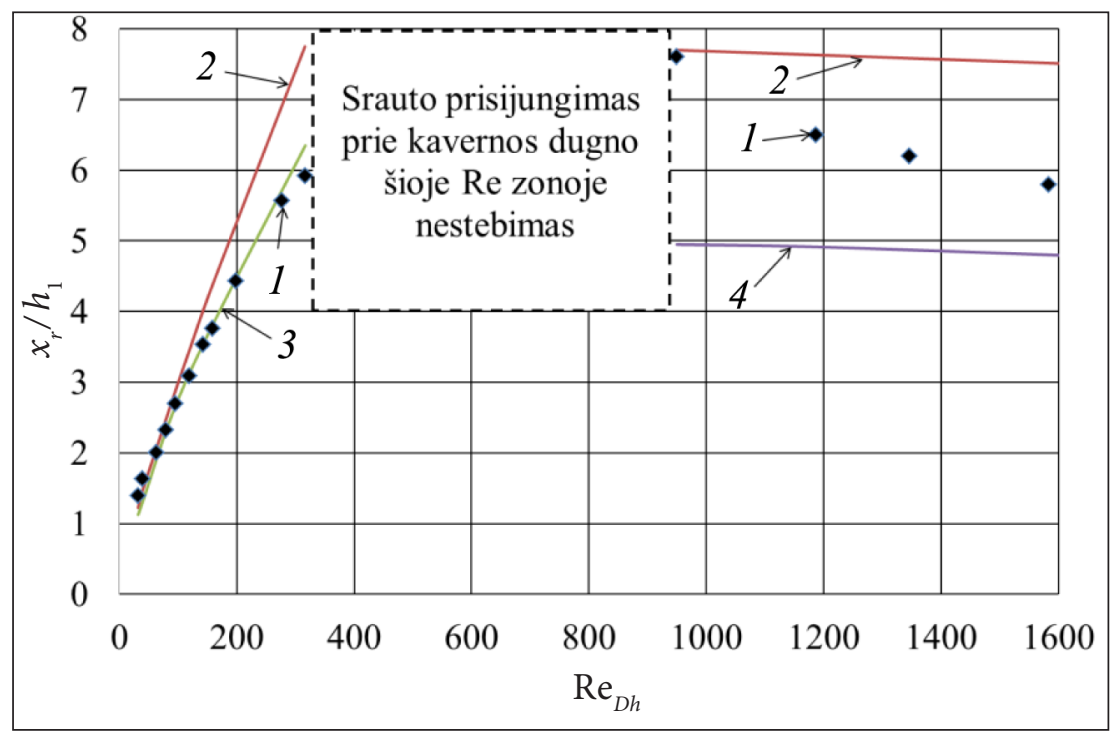

10 pav. Recirkuliacinès zonos ilgio ir kavernos gylio santykio priklausomumas pereinamojo tipo kavernoje nuo $\operatorname{Re}_{D h}: 1$ - eksperimentiniai rezultatai; 2, 3 ir 4 - skaitinis modeliavimas taikant atitinkamai Spallart-Almaras, RSM ir SST $k$-w modelius

ivertinti, rezultatais. Turbulentiniame tekejjimo režime patenkinamus rezultatus teikia RSM ir šlyties įtempimų pernašos (SST k- $\omega$ ) modeliai. Šioje srityje reikia papildomų tyrimų, bet bendroji recirkuliacinès zonos ilgio stabilizacijos tendencija akivaizdi.

Atvirojo tipo kavernoje $(L / h \approx 1)$ (9c pav.) nustatyta sudètingesnè sūkurių struktūra [26]. Pagal 2D matavimus ašinejje kavernos plokštumoje stebimas pagrindinis sūkurys ties kavernos viršum ir priešingos sukimosi krypties antrinis sūkurys kavernos dugne. Pastarasis išryškejja tik didejjant $\operatorname{Re}_{D h^{\text {}}}$. Be to, kintant $\operatorname{Re}_{D h}$ didžiausio greičio zonos keičia vietą pagal pagrindinio sūkurio perimetrą. Tai rodo, kad tokio tipo kavernoje susiformuoja skersiniai pertekejjimai, o srauto struktūra yra trimatè.

11 pav. pateikti tikrojo greičio $(v)$ plokštumoje, einančioje per pagrindinio sūkurio centrą, ir vidutinio greičio kanale $\left(v_{o}\right)$ santykių $\left(v / v_{o}\right)$ reikšmès atsižvelgiant $\mathfrak{i}$ atstumą nuo kavernos atbulinès sienelès $(x / L)$ ir atstumą nuo jos šoninès sienelès $\left(z / h_{1}\right)$. Tikrasis greitis $(v)$ apskaičiuotas pagal greičio komponentes $x$ ir $y$ kryptimis. Juoda rodyklè rodo tekejjimo kanale kryptit; baltos rodyklès - ties kavernos atbuline sienele tekejimo kryptị link kavernos viršaus ir atvirkščiai - ties priekine kavernos sienele - kavernos dugno link.
Greičio minimumas ties $x / L \approx(0,3-0,4)$ skersine $z / h_{1}$ kryptimi rodo pagrindinio sūkurio kavernoje centro padètị. Tačiau greičio minimumas ties $z / h_{1} \approx 0,5$ ašine $x / L$ kryptimi rodo tekejimo kavernoje išsišakojimą (bifurkaciją) i dvi dalis, turinčias savo greičio pikus, kurių padètis priklauso nuo $\mathrm{Re}_{D h^{\prime}}$ Galima daryti prielaidą, kad tokiai sistemai susiformuoti padeda sąveika tarp kanalo kampuose susiformavusių antrinių sūkurinių tekejjimų ir sūkurinio tekejjimo kavernoje.

Jei kanale esant stacionariam tekejjimui išsišakojimas ryškejja laipsniškai tik didejant $\operatorname{Re}_{D h}$, pulsuojančiame sraute ir kai $\operatorname{Re}_{D h}=100$ (11a pav.) jau aiškiai stebimas. Tai reiškia, kad srauto kanale turbulentiškumas pagreitina tekèjimo kavernoje išsišakojimą ir skersinių pertekèjimų atsiradimą.

Šie rezultatai rodo, kad kaverna gali būti naudingu modeliu nagrinejant ir analizuojant sūkurių formavimąsi ir jų sąveikas bei ieškant praktinių uždavinių sprendimų. Ivertinant gautų rezultatų aktualumą ir galimą platų pritaikymą įvairiose inžinerinèse srityse, tyrimai, sprendžiant mikrosrautų dinamikos uždavinius, laboratorijoje bus ir toliau tęsiami, gilinantis ị srauto atitrūkimo valdymo būdus, pasinaudojant aktyviais bei pasyviais metodais, taip pat ir toliau nagrinejant tekejimo struktūrą ir dinamiką aptekant struktūrizuotus paviršius bei kliūtis. 


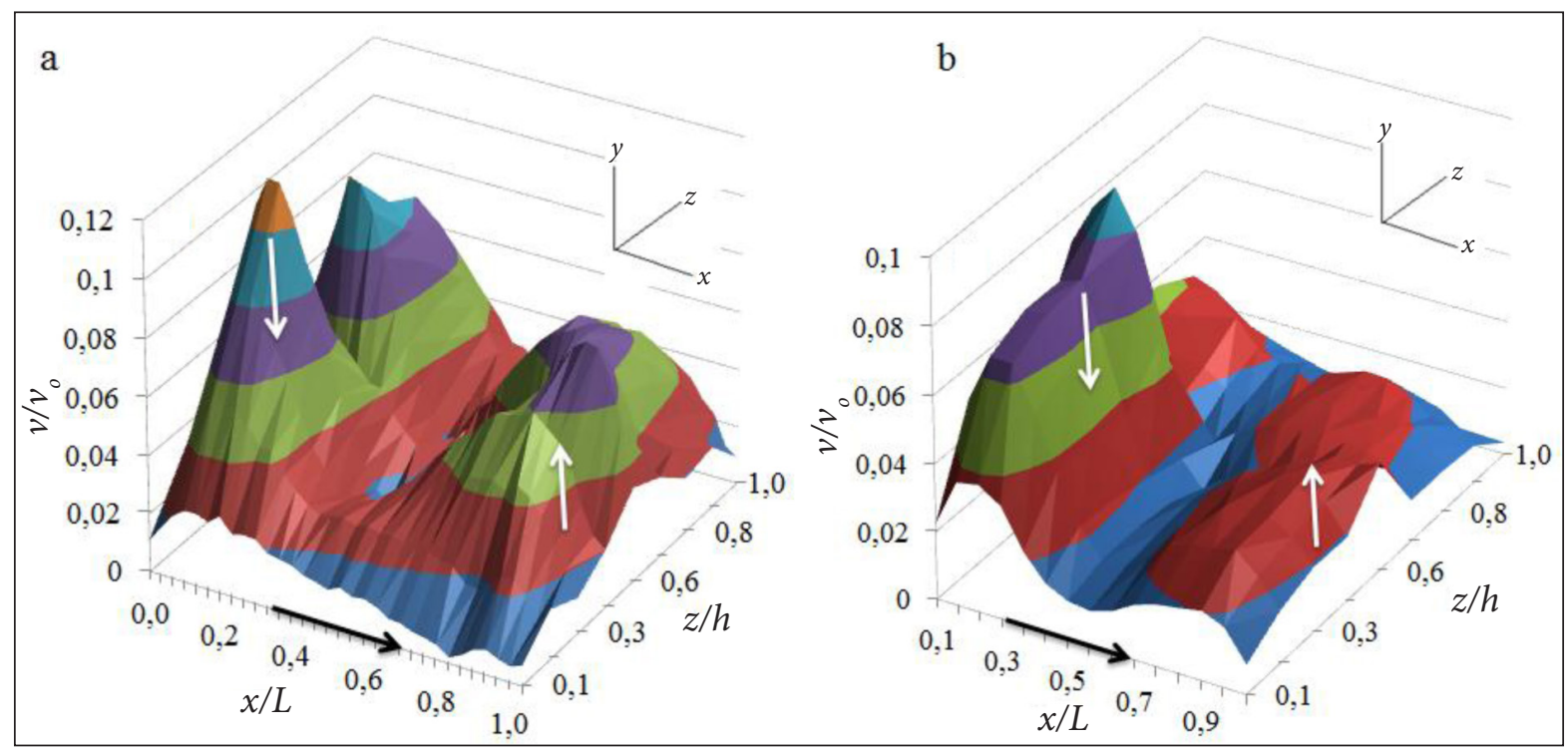

11 pav. Erdvinis greičio profilis per pirminio sūkurio centrą kanale esant pulsuojančiam sinuso formos tekèjimo $40 \mathrm{~Hz}$ dažniui, kai Re: a - 100; b -1000

\section{TAIKOMŲJŲ DARBŲ REZULTATAI}

\section{Skysčiu ir dujų srautų matavimo etalonų bazès plètra ir įteisinimas}

Jau 2002 m. laboratorija, vykdydama Lietuvos Respublikos Vyriausybès igaliojimus sukurti ir išlaikyti valstybinius skysčių ir dujų srautų etalonus, tapo regioninès metrologinès EURAMET organizacijos techninio komiteto Srautai nariu ir pateike pradinius valstybinių etalonų prototipu geriausias matavimo galimybes, nustatyta tvarka pradéjo laipsniškai tobulinti sukurtus etalonus ir siekti tarptautinio pripažinimo. 2005 m. sukurtų 2 etalonų ir 2 prototipu geriausios matavimo galimybès buvo teigiamai įvertintos EURAMET ekspertų, o kokybès vadybos sistema ir pradiniai veiklos rezultatai buvo patvirtinti EURAMET techninio komiteto Kokybe forume Stambule (Turkija). Visa tai reiškè, kad laboratorija įvykdè pagrindinius reikalavimus, keliamus EURAMET organizacijos asocijuotiems paskirtiesiems institutams, vykdantiems ES igaliotų institucijų nustatytus reikalavimus tarptautinei matavimų siečiai užtikrinti srautų matavimo srityje. Pradiniame etape daug reikšmès pripažinimui turèjo atlikti tyrimo darbai ir skelbtos mokslinés publikacijos. Taip pirmą kartą skysčių ir dujų tūrio, debito ir greičio matavimo galimybès buvo paskelbtos Tarptautinio svarsčiu ir matų biuro (BIPM) svetainejje $<\mathrm{http} / / / \mathrm{kcdb}$.bipm. org/appendixC/M/LT/M_LF>.

2008 ir 2014 m. Lietuvos Respublikos Vyriausybè pakartotinai patvirtino 4 valstybinių etalonų sudètį ir jų gerinamas charakteristikas, kurios prieš tai buvo teigiamai įvertintos regioninių metrologinių organizacijų EURAMET, AFRIMETS ir APMP ekspertų. 1 lentelejje pateikti 2016 m.

1 lentelè. Lietuvos energetikos instituto valstybinių etalonų ribos ir išplèstinės neapibrèžtys

\begin{tabular}{|c|c|c|c|}
\hline $\begin{array}{l}\text { Eil. } \\
\text { Nr. }\end{array}$ & Valstybinio etalono pavadinimas & Matavimo ribos & Išplèstinė neapibrèžtis \\
\hline 1. & Oro (dujų) greičio vieneto & nuo $0,05 \mathrm{iki} 60 \mathrm{~m} / \mathrm{s}$ & nuo 8,0 iki $0,45 \%$ \\
\hline 2. & Oro (dujų) tūrio ir debito vienetų & $\begin{array}{l}\text { nuo } 0,016 \mathrm{iki} 9700 \mathrm{~m}^{3} / \mathrm{h} \\
\text { * nuo } 0,0003 \mathrm{iki} 0,016 \mathrm{~m}^{3} / \mathrm{h}\end{array}$ & $\begin{array}{c}\text { nuo } 0,13 \text { iki 0,30 \% } \\
\text { * nuo } 0,31 \text { iki } 0,13 \%\end{array}$ \\
\hline 3. & Skysčių (vandens) tūrio ir debito vienetų & nuo 0,01 iki $100 \mathrm{~m}^{3} / \mathrm{h}$ & nuo 0,054 iki $0,082 \%$ \\
\hline 4. & Skysčiu (naftos ir naftos produktų) tūrio ir debito vienetų & nuo $1 \mathrm{iki} 120 \mathrm{~m}^{3} / \mathrm{h}$ & nuo 0,040 iki $0,065 \%$ \\
\hline
\end{tabular}

* - išplètimas mažų debitų nuo 0,0003 iki $0,016 \mathrm{~m}^{3} / \mathrm{h}$ srityje rengiamas pateikti EURAMET siekiant tarptautinio pripažinimo. 


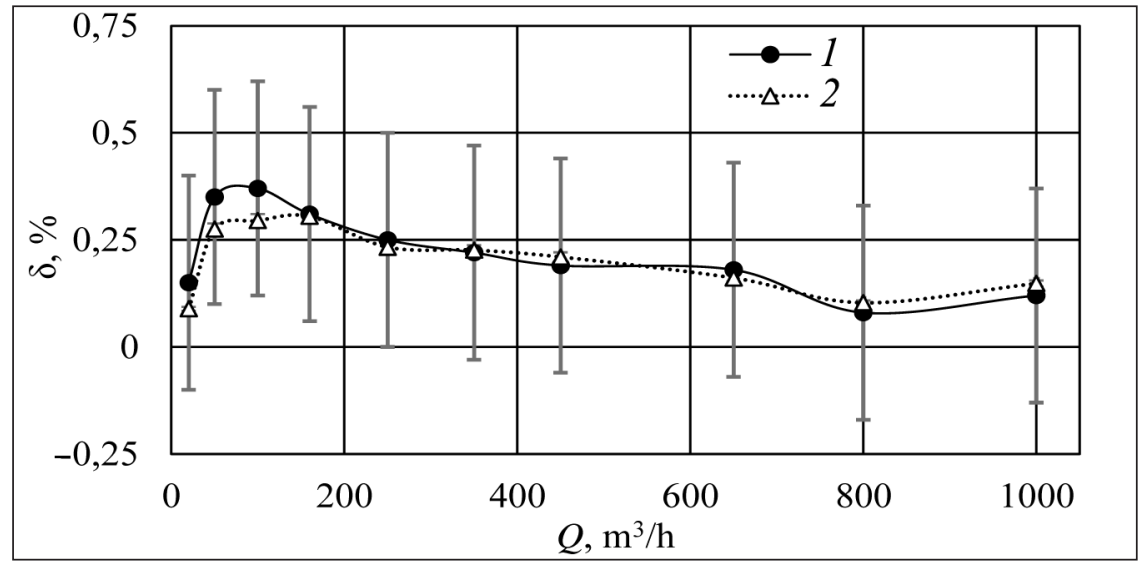

12 pav. 2014-2015 m. tarptautinio palyginimo dujų tūrio esant debitams nuo 20 iki 1000 m³/h matavimo srityje: 1 - LEl rezultatai; 2 - pamatinè palyginimo kreivè

Lietuvos energetikos institute esančių valstybinių etalonų charakteristikos.

2010 ir 2016 m. laboratorijos veikla teigiamai ivvertinta naujai ir pripažinta EURAMET techninio komiteto Kokybe išplèstiniuose posedžiuose Briuselyje (Belgija) ir Sarajeve (Bosnija ir Hercegovina).

\section{Tarptautiniai palyginimai}

Laboratorija visą laiką sèkmingai vykdè vieną pagrindinių reikalavimų - periodiškai patvirtinti pasiektas matavimo ir kalibravimo galimybes dalyvaujant tarptautiniuose matavimų palyginimuose. Toliau pateikiami keli pastarujų palyginimų oro (dujų) ir skysčių (vandens) tūrio, debito ir greičio matavimų srityje pavyzdžiai, kurie parodo Lietuvos valstybinių etalonų veikimo ir matavimų sieties Lietuvoje užtikrinimo lygmenis.

12 pav. pateiktas palyginimas pagal EURAMET projektą Nr. 1296 [27], kuriame dalyvavo 13 Europos šalių nacionaliniai institutai. Palyginimui vertinti taikyta EURAMET pripažinta metodika, kiekvieno dalyvio rezultatų normalizuoto nuokrypio (En) nuo pamatinès vertès dydis turèjo būti mažesnis nei 1.
12 pav. matyti, kad laboratorijos matavimo rezultatai tiksliai atkartoja pamatinius rezultatus. Jei vertintume skirtumą ne vizualiai, bet pagal En dydi, jis kito nuo 0,02 iki 0,30 , vidutinè jo verte prilygo 0,13 .

2015-2016 m. vykdytame EURAMET Nr. 1333 projekte [28], kai buvo palyginami 2 objektai-skaitikliai G2500 ir G6500, LEI laboratorijos normalizuoto nuokrypio En reikšmès buvo tokios, kaip parodyta 2 lenteleje. Lyginant pirmąji objektą dalyvavo 9 šalių nacionaliniai institutai, antrajji - 7 .

Vandens tūrio ir debito matavimo, esant debitams nuo 1 iki $20 \mathrm{~m}^{3} / \mathrm{h}$ ir vandens temperatūrai $50{ }^{\circ} \mathrm{C}$, palyginimuose pagal Nordtest/NIC projektą Nr. 01472 / EURAMET Nr. 863 dalyvaujant 10 ES šalių laboratorijų ir institutų, LEI laboratorijos rezultatų normalizuotas nuokrypis $\mathrm{En}=(0,02-0,56)$, vidutinè reikšmè $-0,20$. Analogiški rezultatai gauti palyginime pagal EURAMET projektą Nr. 1233 [29].

Oro greičio matavimų palyginimai pagal EURAMET projektus (M.FF-K3), 2007-2008 m.; Nr. 514, Nr. 1050, 2011-2012 m. ir Nr. 1225, 2015-2016 m. apima greičių intervalą nuo 0,05

2 Ientelè. Palyginimuose pagal EURAMET projektą Nr. 1333 pasiektos En reikšmès

\begin{tabular}{cccccccccccc}
\hline Debitas, $\mathrm{m}^{3} / \mathrm{h}$ & 1000 & 2000 & 3000 & 4000 & \multicolumn{7}{c}{ Skaitiklis G2500 } \\
\hline En & 0,28 & 0,09 & 0,13 & 0,18 & Vid. 0,17 \\
\hline Debitas, $\mathrm{m}^{3} / \mathrm{h}$ & 1000 & 2000 & 3000 & 4000 & 5000 & 6000 & 7000 & 8000 & 9000 & 10000 & $\begin{array}{c}\text { Skaitiklis } \\
\text { G6500 }\end{array}$ \\
\hline En & 0,12 & 0,21 & 0,21 & 0,13 & 0,07 & 0,06 & 0,08 & 0,06 & 0,00 & 0,02 & Vid. 0,10 \\
\hline
\end{tabular}


iki $40 \mathrm{~m} / \mathrm{s}$. Labai svarbu, kad pastarojo palyginimo intervale nuo 0,05 iki $1,0 \mathrm{~m} / \mathrm{s}$ rezultatai [30] labai gerai koreliavo su pamatiniu svertiniu vidurkiu, kas patvirtino pasiektą aukštą matavimų tikslumą ir matavimo sąlygų stabilumą.

\section{Rezultatų pripažinimas}

Pagrindiniai pripažinimo rodikliai:

- laboratorijos darbuotojų grupé (habil. dr. Antanas Pedišius, dr. Jurij Tonkonogij, dr. Gediminas Zygmantas ir dr. Nerijus Pedišius) pelnè $2008 \mathrm{~m}$. Lietuvos mokslo premiją už 19952007 m. mokslo darbų ciklą „Valstybès etalonų ir eksperimentinès ịrangos komplekso skysčių, dujų ir šilumos kiekių vertėms atkurti ir jų matavimo priemonems tirti ir bandyti sukūrimas" taikomosios mokslinès veiklos (eksperimentinès plètros) srityje;

- 2007-2015 m. laboratorijos darbuotojai apgynė 4 disertacijas [11, 12, 16, 19], kurių tematika glaudžiai siejasi su srautų dinamikos tyrimais matavimo sistemose, kuriose pasireiškia hidrodinaminių trukdžių, fizikinių savybių ir tekejjimo režimų pokyčių įtakos;

- 2011 ir 2015 m. modernizuoti ir iddiegti laboratorijos įrenginiai (pagrindiniai šių darbų vykdytojai - dr. J. Tonkonogij, dr. A. Stankevičius ir dr. A. Tonkonogovas) buvo įvertinti „Lietuvos metų gaminio 2012" aukso medaliu - Kritinių tūtų įrenginys pagal sutartị Nr. 106596/121270.11.11 su AB „Lietuvos dujos“, irengtas AB „Lietuvos dujos" Centrinès kalibravimo ir bandymų laboratorijos Kauno laboratorijoje; aukso medaliu „Mašinų ir įrengimų pramonès“ grupèje „Lietuvos metu gaminys - 2015“ nominacijoje - apdovanotas laboratorijos sukurtas etaloninis varpo tipo ịrenginys, skirtas oro / dujų skaitikliams ir srauto matuokliams kalibruoti, tikrinti ir bandyti.

\section{Taikomosios paslaugos ūkio subjektams}

Be paslaugų, kurias kaip etalonų laboratorija teikia Lietuvos ūkio ir mokslo subjektams kalibruodama matavimo priemones, kitų laboratorijų darbinius etalonus ir irenginius, laboratorija veikia kaip Lietuvos ūkio infrastruktūros dalis, teikianti Lietuvos subjektams akredituotas pagal LST EN ISO/IEC 17025 ir 17020 standartus ir notifikuotas pagal matavimo priemonių direktyvą 2004/22/EB paslaugas. Itin svarbi pastaroji veikla yra Lietuvos ūkio subjektams, gaminantiems arba teikiantiems Lietuvos rinkai matavimo priemones.

Nuo 2008 m., kai laboratorija tapo notifikuota istaiga EB tipo tyrimo bandymams ir atitikties vertinimui atlikti, iki šios dienos laboratorija atliko 23 matavimo priemonių (vandens ir šilumos matuoklių, šilumos energijos skaičiuotuvų, temperatūros jutiklių, srauto jutiklių) tipo tyrimo bandymus pagal Europos Parlamento ir Tarybos direktyvos 2004/22/EB reikalavimus, išdave ES tipo tyrimo sertifikatus. Laboratorijos užsakovai ne tik Lietuvos gamintojai ( $\mathrm{AB}$ „Axis Industries“), bet ir užsienio: Danijos „Danfoss“, Vokietijos „Sensus GmbH“, Italijos „ISOIL Industria“, Lenkijos „Metron“. Per šį laiką dèl gamintojų atliktu prietaisų, kuriems laboratorija išdavè tyrimo sertifikatus, modifikacijų atlikta dvidešimties tipo tyrimo sertifikatų revizijų, kuriuos lydejjo papildomi bandymai ir tyrimai.

Be to, laboratorija, plètodama mažų dujų ir skysčiu srautų matavimo tyrimus, aktyviai dalyvavo taikomojo pobūdžio darbuose, susijusiuose su aktualiais ūkiui uždaviniais, pavyzdžiui, suskystintų dujų tiekimo sistemos iggyvendinimas.

\section{IŠVADOS}

Kryptingi moksliniai ir taikomieji skysčių bei dujų srautų dinamikos kanaluose tyrimai 20062016 m. leido pasiekti šių rezultatų:

1. Išsamiai ištirtas turbininių ir kamerinių matuoklių atsakas $\mathfrak{i}$ ìvairiais désniais pulsuojanti pertekantị srautą ir nustatytas tokių matuoklių dinaminių paklaidų priklausomumas nuo pulsacijų charakteristikų. Sukurtas eksperimentais pagrịstas skaitinio modeliavimo metodas leidžia, vadovaujantis matuoklio atsako i stačiakampi impulsą duomenimis, ịvertinti matuoklio paklaidas esant sudetingiems srauto pulsacijų dèsniams. Nustatyta, kad turbininiams matuokliams pulsacijų ịtaka pasireiškia esant jų dažniui didesniam nei $0,1 \mathrm{~Hz}$, o dažniui esant artimam $2 \mathrm{~Hz}$ pasiekiama ribinè dinaminès paklaidos vertè, kurios dydis priklauso nuo pulsacijų dèsnio ir jų amplitudès.

Tyrimo rezultatai praktikoje leidžia įvertinti netolygaus dujų vartojimo įtaką jų apskaitos tikslumui gamtinių dujų tiekimo sistemose ir technologiniuose procesuose, parinkti priemones pulsacijų lygiui mažinti. 
2. Eksperimentais dujų ir skysčių srautuose, kintant jų kinetinei klampai atitinkamai $(0,44-15) \cdot 10^{-6}$ ir $(0,67-5,5) \cdot 10^{-6} \mathrm{~m}^{2} / \mathrm{s}$ ribose, nustatytas universalus turbininiu ir kamerinių matuoklių dinaminès paklaidos priklausomumas nuo Reinoldso skaičiaus, tekèjimui perejjus ị turbulentinį režimą, ir jos artejimas prie asimptotinio pastovaus lygmens, kai fizikinès klampos itaka darosi itin maža. Šie tyrimo rezultatai turi svarbios reikšmės perkeliant matuoklių kalibravimo laboratorijoje rezultatus ị eksploatacines sąlygas ir kontroliuojant bei prognozuojant galimus matuokliu paklaidų nuokrypius.

3. Mokslinių tyrimo rezultatai panaudoti tobulinant sukurtus keturis valstybinius oro (dujų) greičio ir oro (dujų), vandens ir naftos produktų tūrio ir debito vienetų etalonus iki pripažinimo bei įteisinimo Tarptautinio svarsčių ir matų biuro (BIPM) administruojamoje regioninių metrologijos organizacijų sistemoje. Laboratorija sèkmingai vykdė EURAMET organizacijos, vienijančios Europos šalių nacionalinius matavimų institutus techniniame komitete Srautai, paskirtas funkcijas institutui, ir periodiškai nustatyta tvarka patvirtino savo veiklos rezultatus šios organizacijos techniniame komitete Kokybe.

Sukurti valstybiniai etalonai paskatino plètoti tyrimų ir bandymų techninę bazę, tapti svarbia matavimų infrastruktūros Lietuvoje dalimi, užtikrinančia ne tik tarptautinę matavimų sietí, bet ir Lietuvos ūkyje naudojamų, gaminamų ir teikiamų rinkai srautų parametrų matavimo priemonių atitiktį direktyvų ir reglamentų reikalavimams. Šios veiklos sritys, atsižvelgus i Lietuvos ūkio ir mokslo poreikius, akredituotos ir, kur tinkama, notifikuotos toliau plètoti.

Sukurtas skysčių ir dujų srautų tyrimų ir bandymų kompleksas, rezultatai ịvertinti 2008 m. Lietuvos mokslo premija, etalonų analogai įdiegti Lietuvos ir užsienio laboratorijose bei ịvertinti 2012 ir $2015 \mathrm{~m}$. Lietuvos metu gaminio apdovanojimais.

4. Isisavintas srautų mikrokanaluose tyrimo metodas, pagrịstas dalelių judèjimo sraute vizualizavimu, leidžiantis plètoti naują mokslinių ir taikomųjų tyrimų mikrokanaluose su struktūrizuotais paviršiais kryptị. Nustatyti srauto atitrūkimo ir prisijungimo desningumai pereinamojo tipo kavernose kintant tekejjimo mikrokanale režimui. Parodyta, kad atvirojo tipo kavernoje vyksta srauto išsiskyrimas (bifurkaciją) i dvi šakas, tarp kurių vyksta sudètinga sąveika, lydima skersinių pertekejjimų. Tai nauji rezultatai, leidžiantys spręsti tiek fundamentinius sūkurinių struktūrų sąveikos uždavinius, tiek ir taikomuosius uždavinius, susijusius su kavernų kanalų sienelèse sukeliamais reiškiniais.

Gauta 20160630

Priimta 20160809

\section{Literatūra}

1. Pedišius A. Skysčių ir dujų srautų matavimai energetikoje. Lietuvos mokslas. Lietuvos energetikos institutas 50, 2006. $61 \mathrm{kn}$. P. 177-196.

2. Pedišius A., Tonkonogij J., Stankevičius A. Gamtinių dujų srautų tyrimai ir jų praktinis taikymas. Energetika. 2006. Nr. 3. P. 86-93.

3. Tonkonogii Yu. Analiz dinamicheskoi pogreshnosti turbinnykh schyotchikov gaza. $M a-$ terialy 23-eii mezhdunarodnoii konferentsii "Komercheskii uchyot energonositeleii“. 23-25 maya 2006 g., Sankt-Peterburg, 2006. P. 148-152.

4. Tonkonogij J., Pedišius A. Numerical simulation of the turbine gas meter behavior in the pulsating flow. Journal of Heat Transfer. 2008. Vol. 39. No. 7. P. 559-570.

5. Tonkonogii Yu., Pyadishyus A. Stankevichyus A., Krukovskii P. Dinamicheskaya pogreshnost' turbinnykh schyotchikov gaza v pul'siruyushchem potoke. Promyshlennaya teplotekhnika. 2008. T. 30. Nr. 4. S. 85-93.

6. Tonkonogij J., Pedišius A., Stankevičius A. The new semi-experimental method for simulation of turbine flow meters rotation in the transitional flow. International Journal of Fluid and Thermal Engineering. 2008. Vol. 1. No. 1. P. 30-35.

7. Tonkonogovas A., Krukovskij P. Response and dynamic errors of turbine meter at complex flow pulsation patterns. Industrial Heat Engineering. 2010. Vol. 32(3). P. 99-104.

8. Tonkonogij J., Pedišius A., Stankevičius A., Tonkonogovas A. Dujų srauto pulsacijų įtaka nedidelès šiluminès elektrinès veikimui. Energetika. 2010. T. 56. Nr. 1. P. 19-24.

9. Tonkonogij J., Tonkonogovas A. Analysis of nonlinearity of the turbine gas meters time constant during step response. Mechanika. 2013. Vol. 19(5). P. 526-530. 
10. Bertašienè A., Tonkonogovas A. Inertial properties of the tachometric air velocity meter and their influence on meter's dynamic error in pulsing flow. Proceedings of the 8th International Conference of Young Scientists on Energy Issues CYSENI 2011, Kaunas, Lithuania, May 26-27, 2011. Kaunas: LEI, 2011. P. 256-265.

11. Tonkonogovas A. Pulsuojančio srauto poveikio matuokliu su besisukančiomis dalimis darbui tyrimas: daktaro disertacija. Lietuvos energetikos institutas, 2015. $84 \mathrm{p}$.

12. Maslauskas E. Tekejjimo režimų ir fizikiniu savybiu įtakos dujų ir skysčiu mechaninių debito matuokliu charakteristikoms tyrimas: daktaro disertacija. Lietuvos energetikos institutas, 2014. 79 p.

13. Maslauskas E., Pedišius N., Zygmantas G. Investigation of liquid viscosity influence on flow rate measurement by rotary vane meters. Mechanika. 2014. Vol. 20. P. 158-164.

14. Maslauskas E., Pedišius A., Tonkonogij J. Dujų klampos ittakos turbininiams debito matuokliams tyrimas. Energetika. 2013. T. 59. Nr. 1. P. 50-56.

15. Pedišius N., Zygmantas G., Maslauskas E. Influence of gas and liquid viscosity on turbine and positive displacement meters calibration. Proceedings of the 17th International Congress of Metrology, September 21-24, 2015, Paris, France. P. 6.

16. Bertašienè A. Oro greičio verčiu atkūrimo ir perdavimo tyrimas kintant tekejimo režimui: daktaro disertacija. Kauno technologijos universitetas - Lietuvos energetikos institutas. Kaunas, 2011.95 p.

17. Pedišius A., Janušas V., Bertašienè A. Low air velocity measurement characteristics' variation due to flow regime. World Congress of Science, Engineering and Technology (WCSET 2008), July 4-6, 2008, Paris, France. P. 203-207.

18. Tonkonogij J., Stankevičius A., Pedišius A. Likusios ant ištraukiamo iš skysčio vertikalaus paviršiaus plèvelès tyrimas. Energetika. 2007. Nr. 1. P. 39-44.

19. Stankevičius A. Hidrodinaminiu veiksniu įtakos atkuriamoms oro tūrio ir srauto vertems tyrimas: daktaro disertacija. Lietuvos energetikos institutas. Kaunas, 2007. 90 p.

20. Bertašienè A., Daugelè A., Janušas V. Investigation of practical application of laser Doppler anemometer. Measurement. 2006. No. 2. P. 5-10.
21. Bertašienė A., Janušas V. Different flow regimes and test facility constructions impact on a stable low air velocity value reproduction. Proceedings of the 7th IASME/WSEAS International Conference "Recent Advances in Fluid Mechanics and Aerodynamics (FMA' 09)”, August 20-22, 2009, Moscow. Russia. P. 163-169.

22. Briliūtė I., Bončkus A., Zygmantas G. Influence of installation effects on the performance of residential water-meters. The 7th International Conference: selected papers: May 22-23, 2008, Vilnius, Lithuania, Vol. 2. Vilnius: Technika. P. 785-792.

23. Maslauskas E., Zygmantas G. İrengimo sąlygų itaka srauto matuoklių metrologinems charakteristikoms. Mokslas - Lietuvos ateitis. Pastatu inžinerinés sistemos. 2009. T. 1. Nr. 1. P. 49-51.

24. Zygmantas G., Briliūtè I. Performance of the residential water meters under different conditions of installation. Prace Instytutu Górnictwa Naftowego i Gazownictwa. 2009. No. 162. P. 283287.

25. Vilkinis P., Pedišius N., Valantinavičius M. Vandens tekejjimo mikrokanale tyrimas dalelių vizualizacijos metodu. Energetika. 2015. T. 61. Nr. 2. P. 57-70.

26. Vilkinis P., Valantinavičius M., Pedišius N. Investigation of fluid flow structure in open type cavity under stationary and pulsatile flow conditions. Energetika. 2016. T. 62. Nr. 1-2. P. 37-44.

27. EURAMET project No. 1296. Inter-laboratory calibration comparison of the rotary piston gas meter G650. Final Report - Draft B. Coordinating Institute: T. Valenta, CMI, Czech Republic. December, 2015. P. 75.

28. EURAMET project No. 1333. Comparison of standards for low-pressure gas flow. Report - Draft A. Pilot institute: P. Lucas, G. Blom, VSL, The Netherlands. April, 2016. P. 32.

29. EURAMET project No. 1233. Intercomparison of water meter reference standard. Report - Draft A. Coordinating Institute: B. Akselli, TUBITAK UME, Turkey. February, 2013. P. 22.

30. EURAMET project No. 1225. Intercomparison of very low air speed standard facilities (0.051.0) m/s. Final Report - Draft B. Coordinating Institute: D. Pachinger, BEV/E+E, Austria. June, 2016. P. 21. 
Antanas Pedišius, Jurij Tonkonogij, Nerijus Pedišius, Gediminas Zygmantas, Arūnas Stankevičius, Andrius Tonkonogovas, Agnẻ Bertašienė, Eugenijus Maslauskas, Paulius Vilkinis

STUDY OF GAS AND LIQUID FLOW DYNAMICS IN CHANNELS TOWARDS INCREASE OF VOLUME, FLOWRATE AND SPEED MEASUREMENT ACCURACY

\section{Summary}

The article presents an overview of the main scientific research and development works, performed in the Laboratory of Heat Equipment Research and Resting during the period from 2006 to 2016. Scientific research of gas and liquid dynamics was essentially directed to dependence of accuracy of tachometric gas and liquid volume, flowrate and air velocity meter measurement on flow pulsation and fluid kinematic viscosity, as well as flow regime changes. The patterns of the universal meter dynamic error were estimated during various disturbances and used while assessing flow measurement uncertainty. These patterns were also used, according to the rulings of the Government of the Republic of Lithuania, while implementing and improving four state air (gas) rate and air (gas), water and oil product volume and flowrate standards. The measurement and calibration capabilities of standards were supported by international comparisons, validated, universally recognized and published on the BIPM website.

A developed technical basis of research and testing, as well as the services provided to the economic and scientific subjects make up an important input into the proper functioning of measurement infrastructure in Lithuania as well as assure the conformity assessment of measurement instruments used in practice and manufactured or supplied in the market.

Initial results and applications of perspective research on the flow dynamics in a microchannel with structured surfaces, while using the particle image velocimetry method, are presented.

Keywords: flowrate, volume and flowrate measurement, tachometric meters, pulsatile flow, variable gas and liquid viscosity, dynamic error, flow standards 